\title{
Graphical Analysis for Quality Traits in Sweet Pepper (Capsicum annuum L.)
}

\author{
Baseerat Afroza, S.H. Khan, Azra Lateef* and Labiba R. Shah \\ Division of Vegetable Science, Sher-e-Kashmir University of Agricultural Sciences and \\ Technology of Kashmir, Shalimar-191 121, J\&K, India \\ *Corresponding author
}

\section{A B S T R A C T}

\begin{tabular}{|l|}
\hline K e y w o r d s \\
Capsicum annuum \\
L., Diallel, \\
Graphical analysis, \\
Quality traits \\
\hline Article Info \\
\hline Accepted: \\
18 April 2019 \\
Available Online: \\
10 May 2019
\end{tabular}

\section{Introduction}

At present, the sweet pepper cultivars available for commercial cultivation are either poor yielders and/or with low nutritional quality. This necessitates the development of varieties/hybrids superior in both yield and quality. Hence there is a need to have knowledge on the nature and magnitude of various genetic parameters operative in different characters. This information is of immense importance for selection of best genotypes and appropriate breeding procedure.

Several biometrical procedures are available for evaluation of parents and their crosses to know the nature and magnitude of gene effects for expression of traits. Diallel analysis allows understanding genetic control of the trait, which helps the breeder to advance and select segregating populations. There are several approaches available for analysis of diallel crosses but the two main approaches being followed are Griffing's and Hayman's approaches. These approaches have been successfully used by various scientists in peppers (Sousa and Maluf, 2003; Geleta et al., 2006; Sujiprihati et al., 2007; Rego et al., 2009; Kamble et al., 2009; Grajales et al., 2009; Daryanto et al., 2010).

In addition to this, the $\mathrm{Wr}-\mathrm{Vr}$ statistic calculated from diallel tables, provides an 
estimate of the relative number of dominance to recessive genes present in the common arrays of the parents. The graphs can be drawn for these statistics which can subsequently be interpreted.

\section{Materials and Methods}

The experimental materials for the present investigation consisted of ten diverse genotypes of Sweet pepper (Capsicum annuиm L.) viz., SP-4, SP-21, SP-29, SP-31, SP-32, SP-82, SP-202, SP-614, SP-640 and California wonder (Check) and forty five $F_{1}$ crosses generated from them through $10 \times 10$ diallel mating design. The experimental materials were evaluated at three locations viz., Vegetable Experimental Farm,
SKUAST-K, Shalimar; Krishi Vigyan Kendra, Malangpora and RRS \& FOA Wadura. At each location the experiment was laid out in completely randomized block design with three replications. Recommended package of practices were adopted to raise a healthy crop at all the locations.

\section{Results and Discussion}

The pooled $\mathrm{Wr}-\mathrm{Vr}$ graphs are presented in figures 1. Graphical analysis for all the quality traits under study revealed that some of the parental arrays were clustered around the regression line and some were scattered, indicating the presence of little to moderate amount of genetic diversity among the parents.

Fig.1

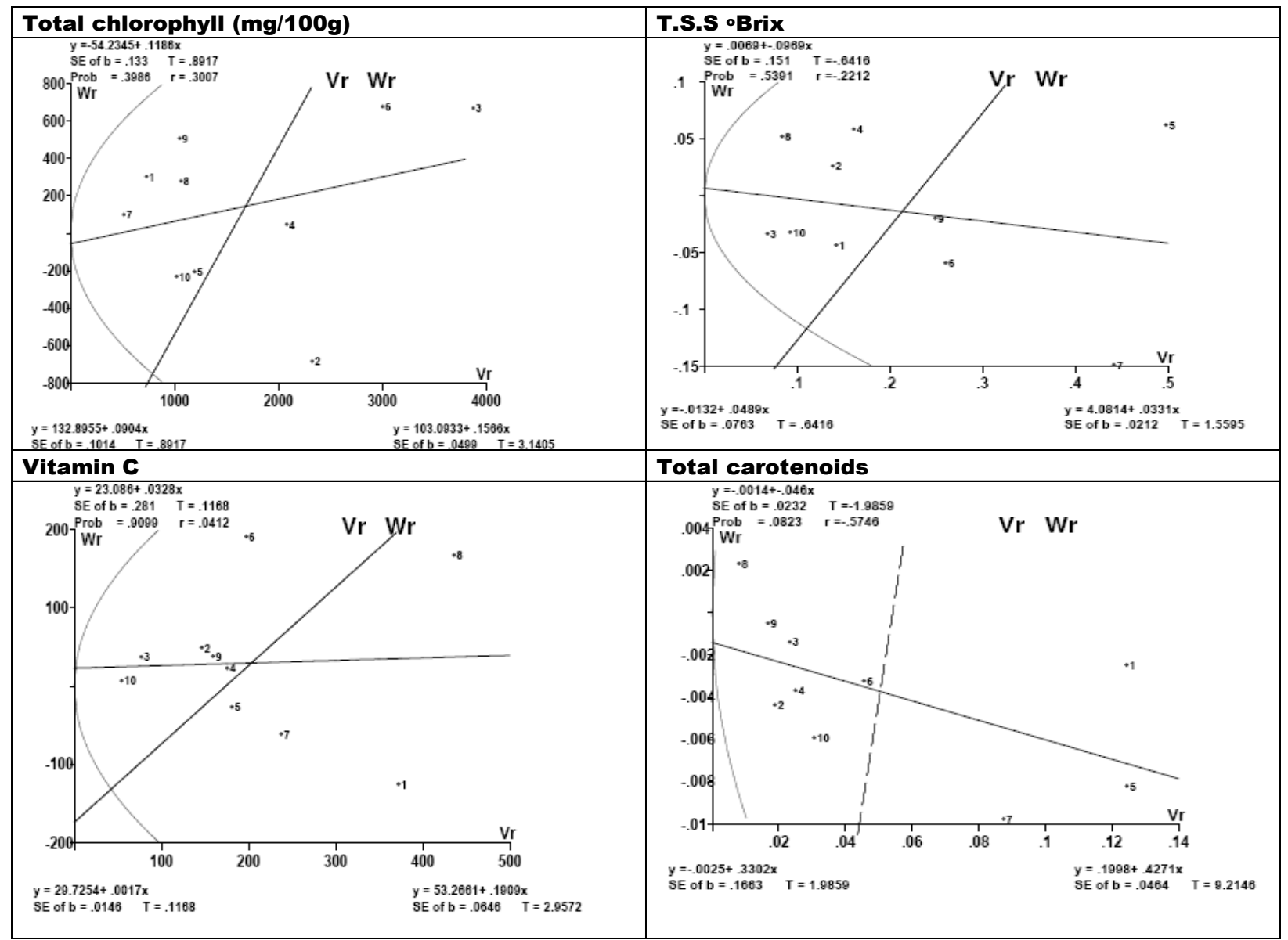


The intersection of regression line with the $\mathrm{Wr}$ axis below the origin revealed over dominance for T.S.S. and total carotenoids. The regression line was found to intersect the $\mathrm{Wr}$ axis above the origin for total chlorophyll and vitamin $\mathrm{C}$ indicating partial dominance.

The parents placed closer to origin suggests that these parents carry more dominant alleles, the parents clustering near the $\mathrm{Wr}-\mathrm{Vr}$ axis intersection indicate the presence of both dominant and recessive alleles in the inheritance of the trait, while as the parents lying farthest indicate the presence of more recessive genes. For all the quality traits under study, the parents were positioned away from the point of origin indicating the importance of both dominant and recessive alleles for the expression of these traits. For total chlorophyll, the parents P2, P3 and P6 being farthest exhibited importance of recessive alleles. For T.S.S., the parents P3, P5, P7 and P8 were lying farthest from the origin depicting the role of recessive alleles. The intermediate positions of rest of the traits depicted the contribution of both dominant and recessive alleles. For vitamin C, the parents P1, P6 and P8 exhibited role of recessive alleles being placed farthest. Rest of the parents exhibited the role of both dominant and recessive alleles. For total carotenoids, the parents P1, P5, P7 and P8 were lying far away from the point of origin indicating the contribution of recessive alleles. For rest of the parents, disparities were observed for the presence of dominant and recessive genes. Similar results have also been reported by Sousa and Maluf (2003) and Hussain et al., (2017) for various traits in hot pepper.

\section{References}

Cruz., C.D., and Regazzi, A.J 1994. Modelos biometrics aplicados ao melhoramento genetic. Vicosa: UFV $390 \mathrm{p}$

Daryanto, A., Sujiprihati, S. and Syukur, M. 2010. Studi heterosis dan daya gabung Karaker agronomi cabai (Capsicum annuum L.) pada persilangan half diallel. Journal Agron. Indonesia 38: 114-121

Geleta, L.F., Labuschagne, M.T. and Maryke, T. 2006. Combining ability and heritability for vitamin $\mathrm{C}$ and total soluble solids in pepper (Capsicum annuum L.). Journal of Science Food Agriculture. 86 (9): 1317-1320.

Grajales, M.P., Hernandez, V.A.G., PennaLomdi, A and SahangienCastellanos, J. 2009. Combining ability and heterosis for fruit yield and quality in manzano hot pepper (Capsicum pubescens $\mathrm{R} \& \mathrm{P}$ ) landraces. Revista Chapingo Serie Horticulture 15 (1): 47-55.

Hussain, K., Khan, S. H., Parveen, K., Afroza, B., Makhdoomi, M.I., Mushtaq, F. and Nazir, G.2017. Graphical Analysis for Quality Traits In Brinjal (Solanum melongena L.). Economic Affairs 63:1-4

Kamble, C., Mulge, R. and Madalageria, M.B. 2009. Combining ability for earliness and productivity in Sweet pepper (Capsicum annum L.). Karnataka Journal of Agricultural Sciences 22 (1): 151-154

Ramalho, M.A.P., Santos, J.B. and Zimmermann, M.J. 1993. Genetica quantitative em plantas autogamas, Goiania: UFG, Pp-271

Rego, E.R., do Rego, M.M., Finger, F.L., Cruz, C.D. and Casali, V.M.D. 2009. A diallel study of yield components and fruits quality in chilli pepper (Capsicum baccatum). Euphytica 168:275-287

Sousa, J.A-de and Maluf, W.R. 2003. Diallel 
analysis and estimation of genetic parameters of hot pepper (Capsicum chinense Jacq.) Scientia Agricola 60 (1):105-113.

Sujiprihati, S., Yunianti, R., Syukur, M. and Undang 2007. Pendugaan nilai heterosis dan daya gabung beberapa komponen hasil pada persilangan diallel penuh enam genotype cabai (Capsicum annuum L.) Bul. Agron. 35: $28-35$

Vencovsky, R., and Barriga, P. 1992. Genetic biometric no fitomelhoramento. Ribeirao Preto: Sociedada Brasileira de Genetica. Pp-496.

\section{How to cite this article:}

Baseerat Afroza, S.H. Khan, Azra Lateef and Labiba R. Shah. 2019. Graphical Analysis for Quality Traits in Sweet Pepper (Capsicum annuum L.). Int.J.Curr.Microbiol.App.Sci. 8(05): 2355-2358. doi: https://doi.org/10.20546/ijcmas.2019.805.278 